\title{
Hydrochemistry and phytoplankton composition of two tidal creeks in South-Western Nigeria
}

\author{
Taofikat Adesalu, Micheal Bagbe \& Dare Keyede \\ Department of Botany and Microbiology, University of Lagos, Nigeria; boseadesalu@yahoo.com
}

Received 26-VII-2009. C Corrected 03-II-2010. Accepted 11-III-2010.

\begin{abstract}
As in other countries, the effects of human stressors on coastal areas and waters in Nigeria are increasing, and management strategies are urgent. In order to assess this, studies on phytoplankton composition in relation to physico-chemical characteristic of two tidal creeks in Lagos were conducted for six months (October 2007 to March 2008). Variations in some of the physical and chemical parameters such as rainfall, temperature, salinity, nitrate-nitrogen, phosphate-phosphorus, sulphate, salinity, biological oxygen demand and chemical oxygen demand influenced the phytoplankton abundance. Three major divisions were recorded for the two creeks: Bacillariophyta, Chlorophyta and Cyanophyta. Among these, diatoms were the most abundant group observed. Water quality characteristics reflected the effect of tidal influence and consequent salt water inflow, fresh water incursion and the pollution status of one of the creeks, as a result of industrial and commercial activities in the area. Rev. Biol. Trop. 58 (3): 827-840. Epub 2010 September 01.
\end{abstract}

Key words: tidal creek, phytoplankton, tropics, pollution.

Lagos lagoon with a surface area of $208 \mathrm{~km}^{2}$ is open, tidal and brackish, the lagoon is connected and non parallel to the Gulf of Guinea coastline over a distance of $237 \mathrm{~km}$ (Hill \& Webb 1958). It cuts across the Southern part of the metropolis, linking the Atlantic Ocean (in the West and South) and Lekki lagoon (in the East). It is tidal and shallow with an average depth of $1.5 \mathrm{~m}$ except at channels that are continually dredged to accommodate heavy water traffic (Oyenekan 1988). The Lagos Lagoon consists of three main segments: Lagos Harbour, the Metropolitan end and Epe division segments. According to Okusipe (2004), the pollution level of the lagoon is greatest in the Lagos harbour segment and decreases in the metropolitan end of the lagoon, while Epe segment records the least level of pollution. The lagoon provides places of abode and recreation, means of livelihood and transport, dumpsite for residential, industrial discharges and a natural shock absorber to balance forces within the natural ecological system. It also provides a good platform for inland waterways transportation which has potentialities of reducing transportation problems in Lagos metropolis. Sewage, wood waste, refine oil, waste heat, municipal and industrial effluents among others find their way unabated into immediate coastal waters through conduits such as storm water channels, rivers, creeks and lagoons (Akpata et al. 1993, Chukwu \& Nwankwo 2004). Creeks are common hydrological features in South-Western Nigeria and are essentially of two types. The tidal freshwater/brackish creeks surrounded partly by mangrove swamps and partly by freshwater swamps from points beyond the reach of tidal influence and the non-tidal freshwater creeks, surrounded by freshwater swamps and usually infested with aquatic macrophytes all through the year (Adesalu \& Nwanko 2005). Creeks in this region gravitate 
to coastal lagoons in their immediate area enrooted to the sea via the Lagos harbour. The existence of environmental gradients keyed to rainfall distributive pattern and more discernable in the dry season has been reported by researchers for the Lagos lagoon and adjoining creeks extending East and Westward from the harbour (Olaniyan 1969). Recently, the pollution hazards of coastal waters like the Lagos lagoon, have increased due to indiscriminate use of petroleum products, detergents and heavy metals and dredging (Ohimain 2004, Ajibola et al. 2005). Some workers (Greenway \& Gordon-Smith 2006, Howarth \& Marino 2006) have reported that diatoms favors nutrient-rich environments especially nitrates.

Recent phytoplankton studies of some creeks in South-West Nigeria include: Adesalu \& Nwankwo $(2005,2008)$ on Olero and AbuleEledu creeks respectively; Adesalu et al. (2008) on Ogbe creek and Emmanuel \& Onyema (2007) on the Abule-Agege creek. Other algal genera associated with organically enriched water included Euglena, Nitzschia, Phacus and Closterium (Palmer 1969, Munawar 1972). This study was undertaken to show some of the effects of human stressors on the coastal waters of Nigeria.

\section{MATERIALS AND METHODS}

Study area: The Ajegunle, creek (Fig. 1) is located at Apapa area of Lagos state; it empties into the Badagry creek then into the Lagos lagoon. The creek is tidal and used as a means of transportation of goods and people around some parts of the city. It is bordered by a predominantly rural community showing very little sign of urbanization. The creek is marked by the presence of high rate of pollution from surrounding residents which is evident by the large amount of refuse deposited at the banks of the creek and sewage floating on the water surface into which toilets and bathrooms have been constructed. Tomaro creek (Fig. 1) is located on the West of the Lagos harbour and flows into the sea all times of the year. Tomaro creek is a relatively undisturbed natural environment as it is one of the few areas of the Lagos lagoon that is not either surrounded by industries nor urbanization, thus is not exposed to direct influx of pollutants. However, due to the activities of oil bunkers in the area, there have been reports of oil dripping into the creek. The two creeks are shallow, like most other part of the Lagos lagoon and experience semi-diurnal tidal oscillations.

Methods of collection: Two stations were created each to reflect confluence of the creeks in to the Lagos lagoon, Ajegunle $\left(06^{\circ} 26^{\prime} 34\right.$ $\left.06^{\circ} 26^{\prime} 58 \mathrm{~N}, 003^{\circ} 20^{\prime} 56-003^{\circ} 21^{\prime} 06 \mathrm{E}\right)$ and Tomaro $\left(06^{\circ} 25^{\prime} 09-06^{\circ} 26145 \mathrm{~N}, 003^{\circ} 22^{\prime} 46-\right.$ $003^{\circ} 22152 \mathrm{E}$ ) as stations A and B. Biological samples were taking using standard plankton net of $55 \mu \mathrm{m}$ mesh size towed steadily for ten minutes at low speed and preserved in $4 \%$ unbuffered formalin. For physico-chemical analysis, water samples were stored in $1 \mathrm{~L}$ properly labeled plastic containers with screw caps and transported to the laboratory in ice-chests. All samples were collected during the hours of daylight to minimize variations due to diurnal migration.

Physico-chemical analysis: Surface water samples were analyzed using APHA 1998 methods. Air and water temperatures were measured in-situ using mercury in glass thermometer while the $\mathrm{pH}$ was determined with Electronic Cole Parmer Testr3. Gravimetric method was applied for both total dissolved and suspended solids while Secchi disc and HANNA instruments were used for transparency and salinity respectively. Dissolved oxygen and chemical oxygen demand were determined using Titrimetric method, Winkler's method was applied for the determination of biological oxygen demand, acidity and alkalinity values were measured using titration method. Colorimetric method was applied for the nutrients contents (nitrate-nitrogen and phosphatephosphorus), conductivity was measured using Philips PW9505 conductivity meter, Titrimetric method was used to determine Calcium, Magnesium, Chloride and total hardness content of 

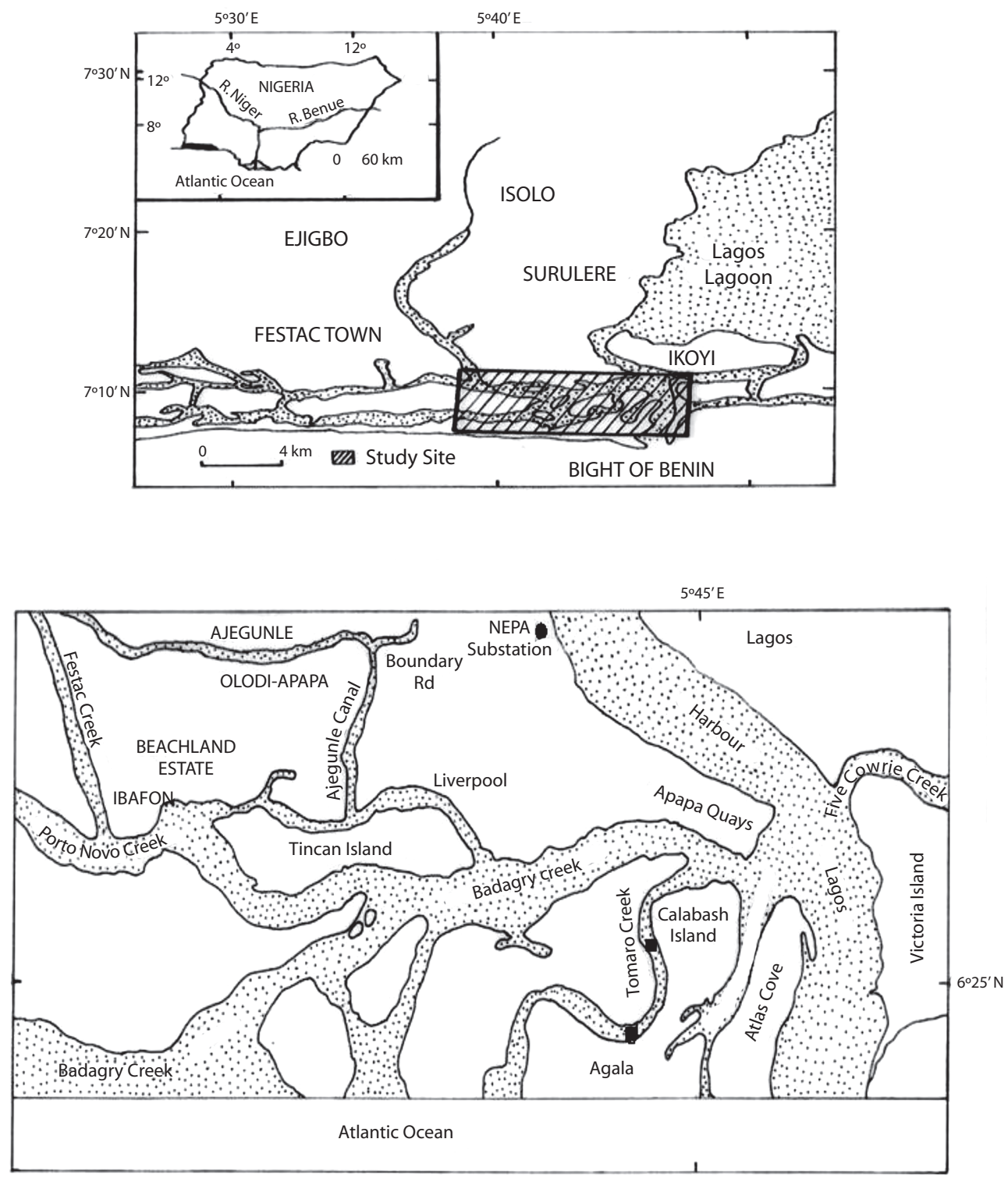

Fig. 1. The Apapa area of Lagos showing major Creeks and Sampling site (cuadro negro).

surface water samples while Atomic Absorption Spectrophotometer analyzed Zinc Iron and Copper content of the water samples. Turbidimetric method was used for sulphate, Colorimetric and Florometric methods were applied for silica and chlorophyll-a (APHA 1998).
Phytoplankton identification: In the laboratory, biological samples were analyzed using Olympus XSZ-N107 photomicroscope. In this study, filamentous blue green were counted using $10 \mu \mathrm{m}$ of filament length representing one unit unicells and solitary cells 
were tallied as separate individuals. Since many algae are colonial and consist of a few to many cells, for Microcystis sp the method used for filamentous algae was applied. For further analysis, one unit was equated as one cell. Relevant texts employed in the identification included (Adesalu 2007, Nwankwo 1984, Olaniyan 1969, 1975, Whitford \& Schumacher 1973, Wimpenny 1966).

Community structure analysis: To obtain the estimate of species diversity, three community structure indices were used: Margalef's diversity index (d), Shannon-Weaner Index $\left(\mathrm{H}^{1}\right)$ (Shannon \& Weaver 1963) and Species Equitability (J) or Evenness (Pielou 1975).

\section{RESULTS}

Physico-chemical parameters: The results of the physico-chemical parameters analyzed in this study are presented on Table 1. Throughout the sampling period for the two creeks, the highest surface water temperature value $\left(31{ }^{\circ} \mathrm{C}\right)$ was recorded at Tomaro while Ajegunle recorded the lowest value $\left(24^{\circ} \mathrm{C}\right)$, the $\mathrm{pH}$ was slightly alkaline with highest value (7.80) recorded in October for Ajegunle creek. Tomaro creek maintained high transparency values with highest $(139.20 \mathrm{~cm})$ recorded in February 2008 (Fig. 2a) while Ajegunle remained turbid with highest value $(25.10 \mathrm{~cm})$ recorded in March 2008 (Fig. 2b). Salinity decreased steadily in the water bodies as rainfall increased, the highest value $(23.20 \%$ ) recorded was in Tomaro creek (Fig. 2a). Phosphate-phosphorus and nitrate-nitrogen highest values $(12.50 \mathrm{mg} / \mathrm{L}$ and $12.10 \mathrm{mg} / \mathrm{L})$ were observed at Ajegunle creek (Fig. 3b). Highest chlorophyll-a value $(66.00 \mu \mathrm{g} / \mathrm{L})$ was recorded in Tomaro creek February 2008 (Fig. 3a) while the lowest value $(4.00 \mu \mathrm{g} / \mathrm{L})$ was recorded in Ajegunle creek (Fig. 3b). Silica content of the water was highest $(4.30 \mathrm{mg} / \mathrm{L})$ in December 2007 at Ajegunle while Tomaro recorded the lowest value $(1.60 \mathrm{mg} / \mathrm{L})$ in October 2007. Total dissolved and total suspended solids highest values $(20508 \mathrm{mg} / \mathrm{L}$ and $2210 \mathrm{mg} / \mathrm{L}$ ) were recorded in Tomaro and Ajegunle creeks respectively. Conductivity and chloride ions values followed the same pattern for the two creeks (Table 1).

Biological samples: 24 taxa belonging to 19 genera were observed in this study. Out of these recorded taxa, Tomaro creek had a total of 11 taxa from nine genera, while Ajegunle creek recorded 18 taxa belonging to 15 genera. Bacillariophyta, Cyanophyta and Chlorophyta were the three divisions represented in the two creeks. Of all the species identified, Coscinodiscus nitidus, Parabelus delogni, Spirogyra africanum, Anabaena torulosa and Chroococcus sp. were not recorded in Ajegunle creek. Highest species diversity (2.17) was recorded in January at station B in Ajegunle while station A Tomaro in February 2008 had the lowest value (0.20) (Fig. 4a). Highest and lowest Shannon-Weaver index values (2.53 and 0.13 ) were recorded in Ajegunle creek (Fig. 4b). Variation in Shannon-Weaver information $\left(\mathrm{H}^{\mathrm{I}}\right)$ and Equitability ' $j$ ' in these two creeks follow each other closely, with the lowest values found in November 2007 (Figs. 4a and 4b). For both creeks, the algal flora was dominated by diatoms followed by blue-green and green algae (Table 2).

\section{DISCUSSION}

Ajegunle creek: Dissolved oxygen was found to decrease as salinity increases which is similar with the observation made by Chapman (1992) that the solubility of oxygen decreases as salinity increases. This trend was probably as a result of domestic sewage from various activities of human residing around the study area, reception of effluents containing oxygen-demanding substances. Biological oxygen demand $\left(\mathrm{BOD}_{5}\right)$ and chemical oxygen demand values recorded for this creek at both stations increased as dissolved oxygen values decreases; these are likely pointers to pollution stress to which the creek is exposed. According to Nwankwo \& Akinsoji (1989), the Lagos Lagoon is under intense pressure 


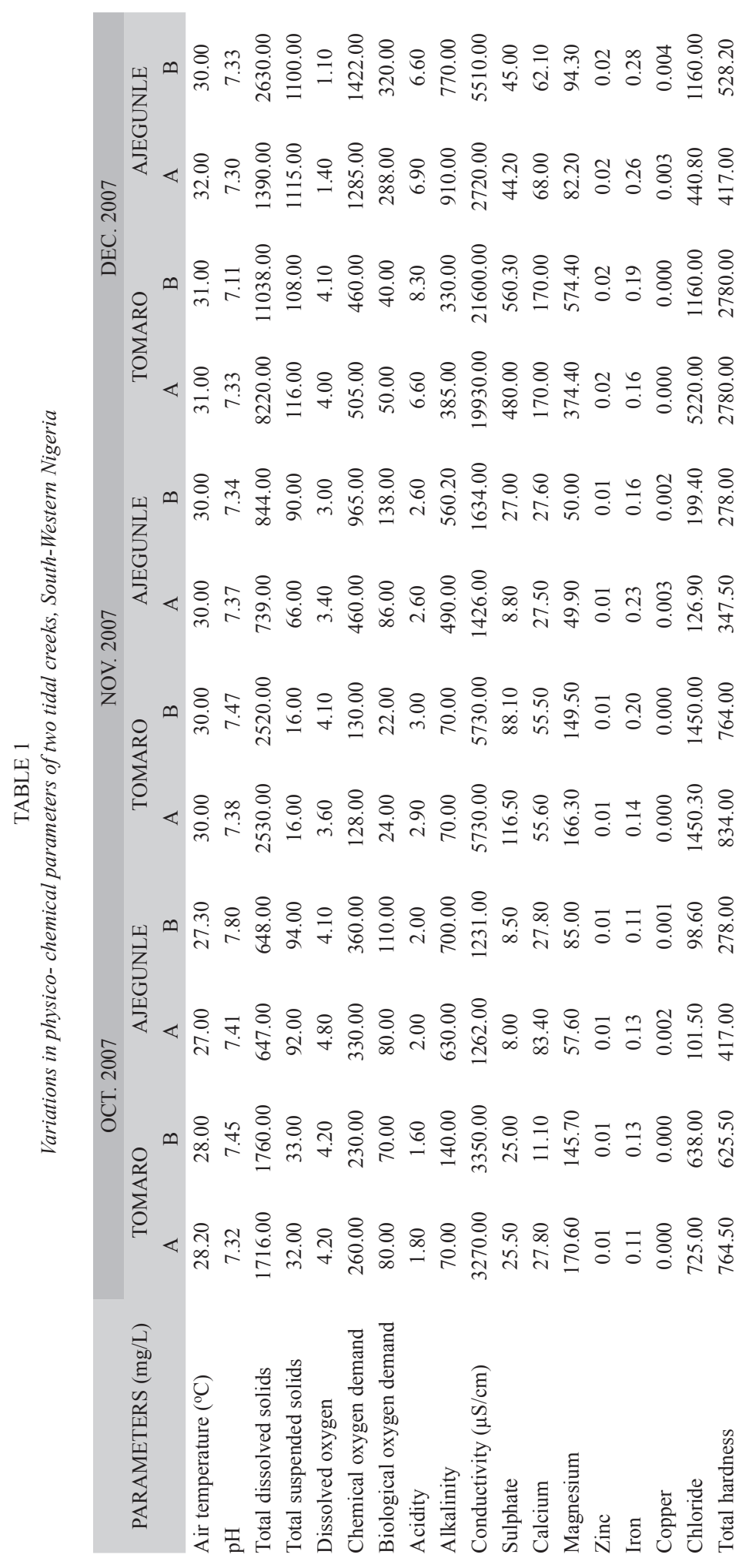




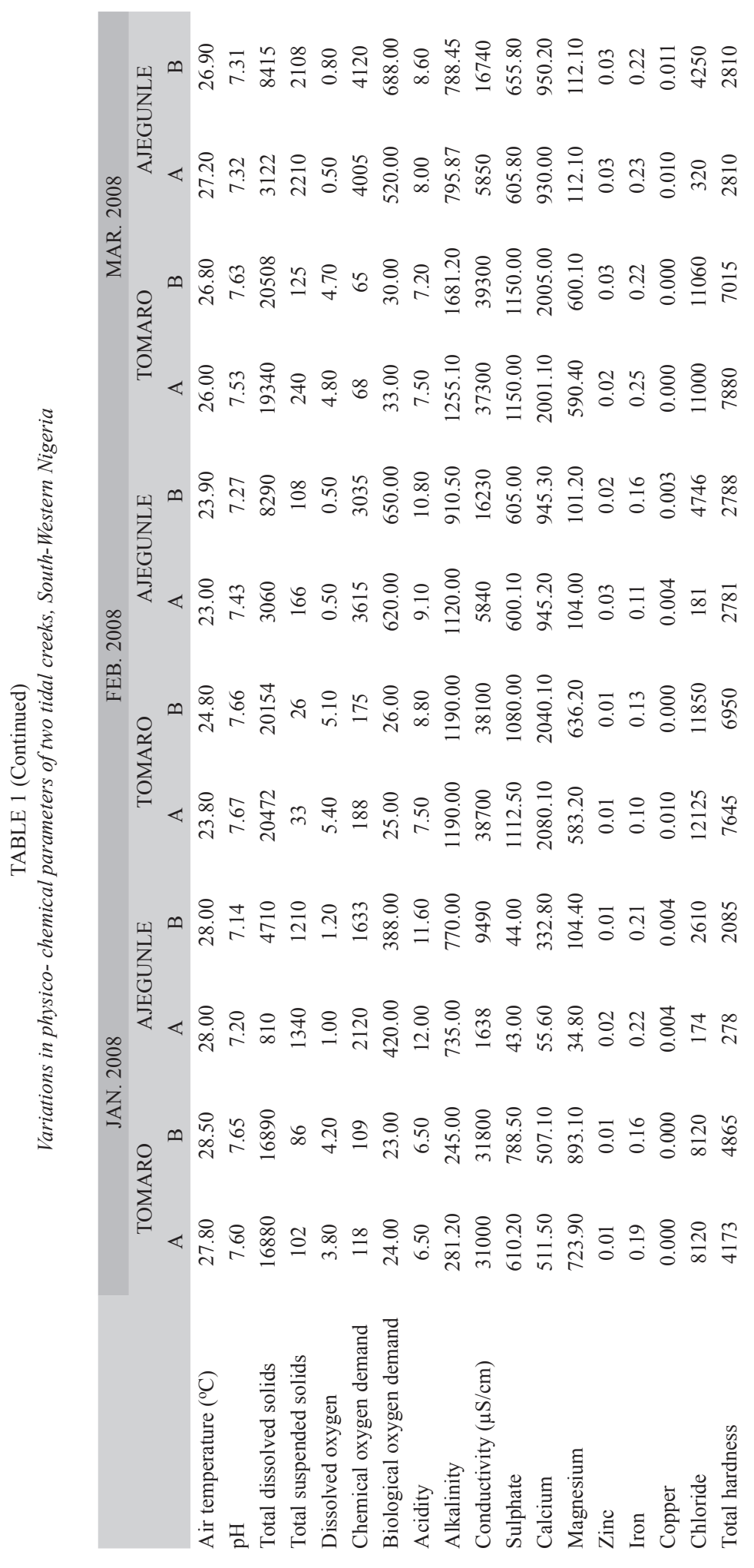



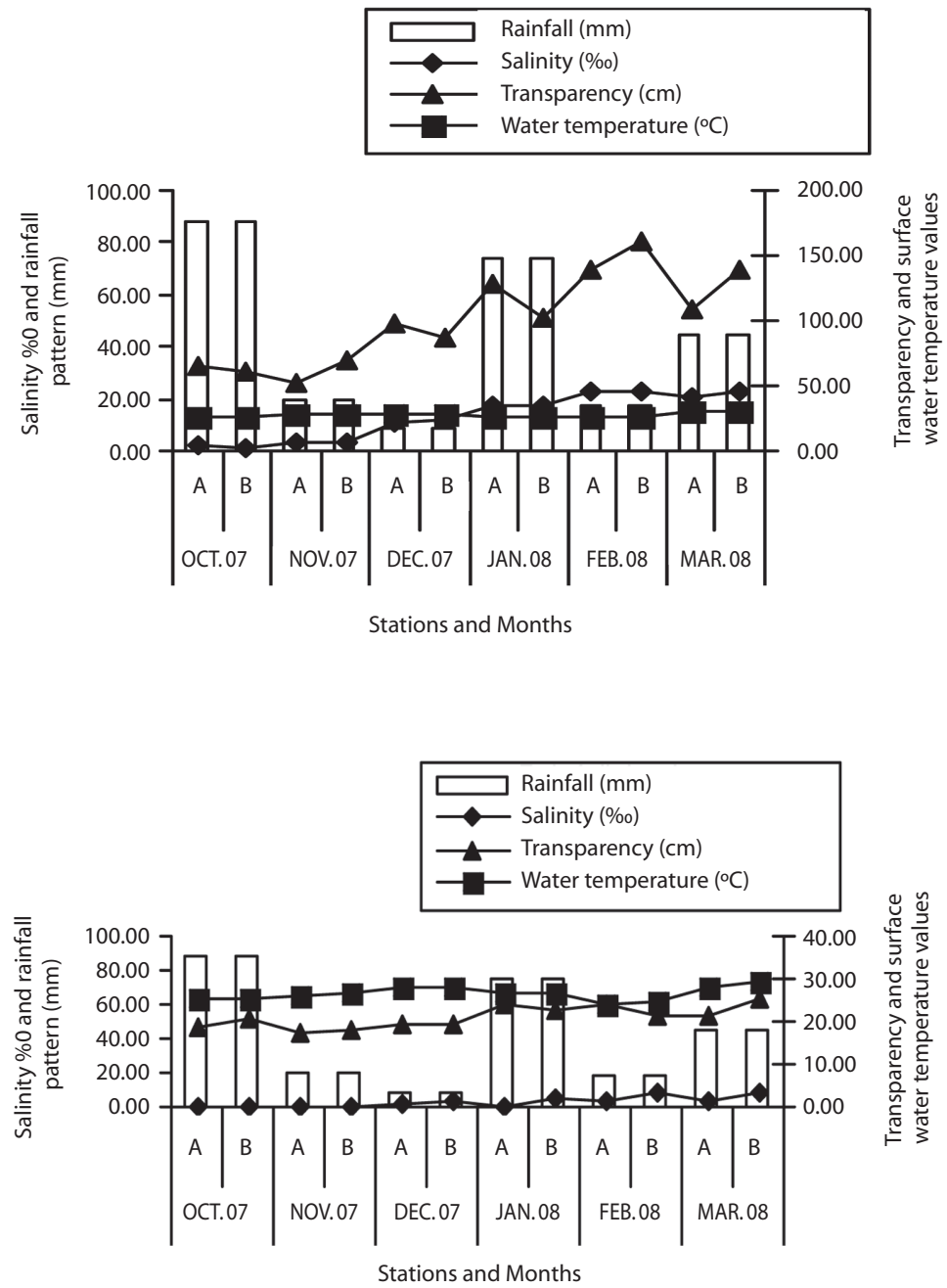

Fig. 2. A. Variations in rainfall pattern, salinity, transparency and surface water temperature at Tomaro creek. B. Variations in rainfall pattern, salinity, transparency and surface water temperature at Ajegunle creek.

from pollution such as untreated sewage, sawdust, petrochemical materials, detergent and industrial effluents. As observed, the diatoms spectrum recorded was high in March and similarly, high values for nitrate concentrations $(12.1 \mathrm{mg} / \mathrm{L}$ and $8.8 \mathrm{mg} / \mathrm{L})$ at stations $\mathrm{A}$ and $\mathrm{B}$ respectively were recorded in March. High levels of nutrients usually give rise to high abundance of some micro algal species in aquatic water environments (Nwankwo 2004). Similar regime has also been observed by some workers (Patrick 1948, Blum 1957) where they reported that diatoms are favored in nutrients rich environment particularly nitrates. Further suggestion was made when the highest number of total phytoplankton composition observed in January correlated with the highest value of phosphate recorded in the same month and also the lowest values of phosphate recorded in December reflected on the phytoplankton abundance at both stations. 

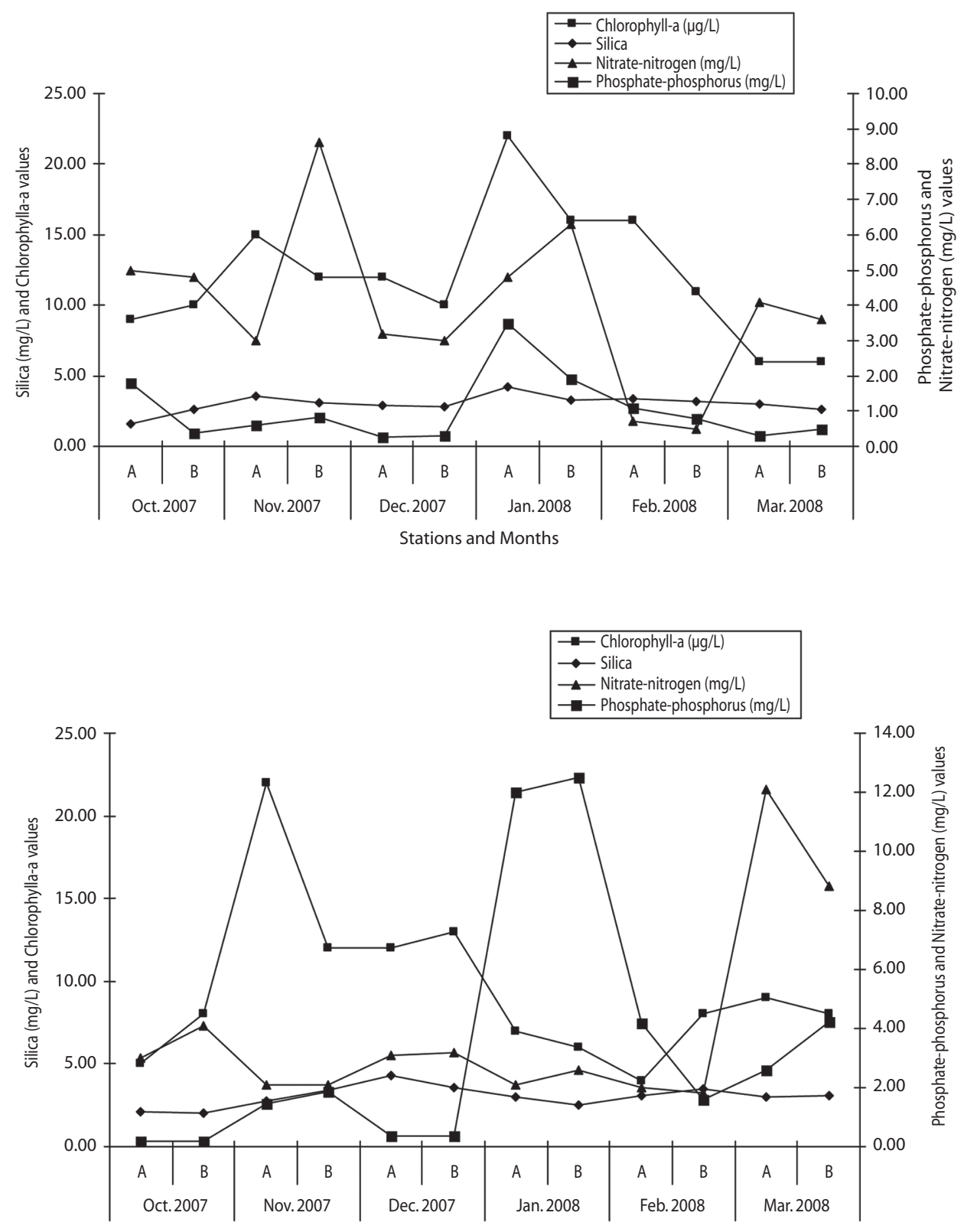

Stations and Months

Fig. 3. A. Relationships between Phosphate-phosphorus, Nitrate-nitrogen, Silica and Chlorophyll-a content at Tomaro creek. B. Relationships between Phosphate-phosphorus, Nitrate-nitrogen, Silica and Chlorophyll - a content at Ajegunle creek. 


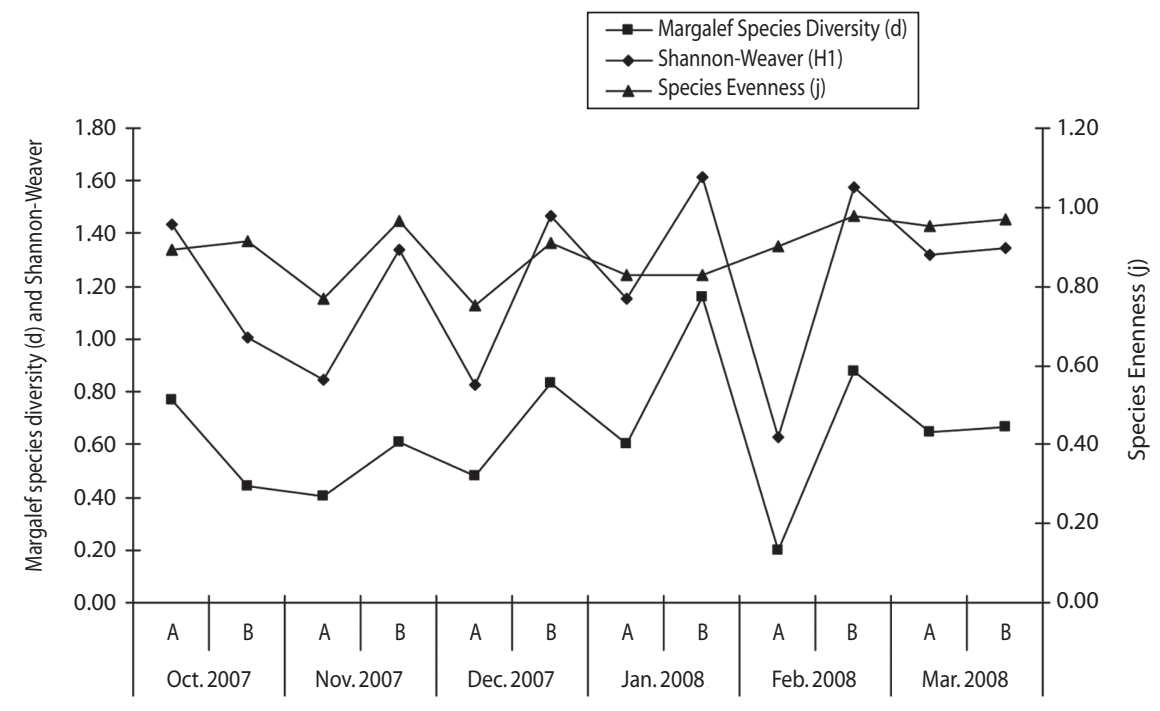

Stations and Months

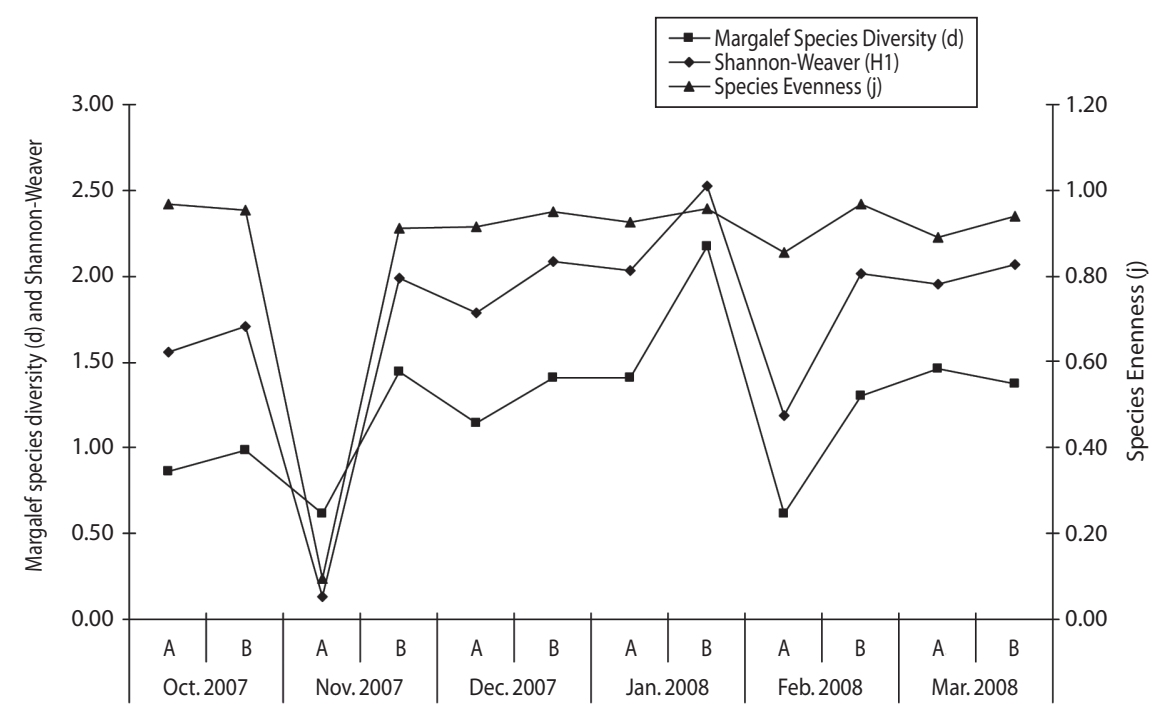

Stations and Months

Fig. 4. A. Relationships between the diversity indices at Tomaro creek. B. Relationships between the diversity indices at Ajegunle creek. 
TABLE 2

Phytoplankton composition and abundance (cells/mL) at Tomaro and Ajegunle creeks

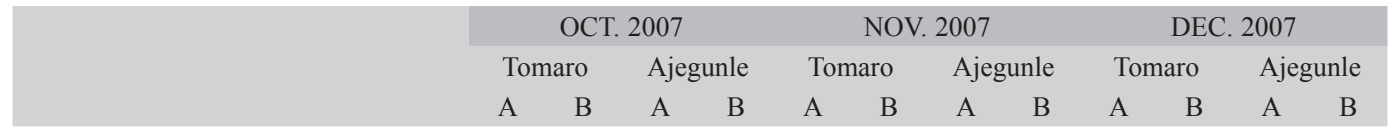

Division: Bacillariophyta

Class: Bacillariophyceae

Order1: Centrales

Aulacoseira granulata Ehr.

Coscinodiscus centralis Ehr.

C. lineatus Ehr.

C. nitidus Ehr.

$\begin{array}{cccccc}- & - & & 24 & - & 25 \\ 38 & - & 22 & 10 & - \\ 80 & - & & & 90\end{array}$

Cocconeis placentula Ehr.

30

Cyclotella meneghiana (Kutz) Grunow

Diatoma elongatum

Fragillaria construens Ehr.

Nitzschia palae (Kutzing) Wm Smith

Parabelus delogni

Pinnularia brauni

Pleurosigma strigosum W. sm.

Synedra ulna (Nitzsch) Ehr.

Division: Chlorophyta

Class: Chlorophyceae

Order: Desmidiales

Closterium lineatum Ehr.

20

20

45

10

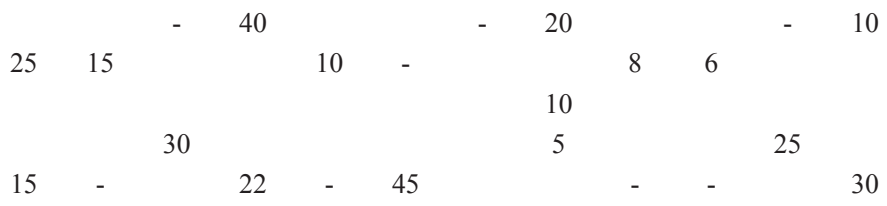

Order: Zygnematales

Spirogyra africanum Fritch

$25 \quad 47$

$12 \quad 35$

Division: Cyanophyta

Class: Cyanophyceae

Order I: Chrooccocales

Chroococcus sp.

$-\quad 29$

46

$45 \quad 35$

Order II: Hormogonales

Anabaena torulosa Lagerheim

Lyngbya martensiana

Microcystis aeruginosa Klebahn

Oscillatoria bornetti

O. formosa Bory

O. limosa Agardh

O. sancta (Kutz). Gom

Spirulina platensis Geitler

Number of species

Total number of individuals

Margalef Species Diversity (d)

Shannon-Weaver $\left(\mathrm{H}^{1}\right)$

Species Evenness (j)

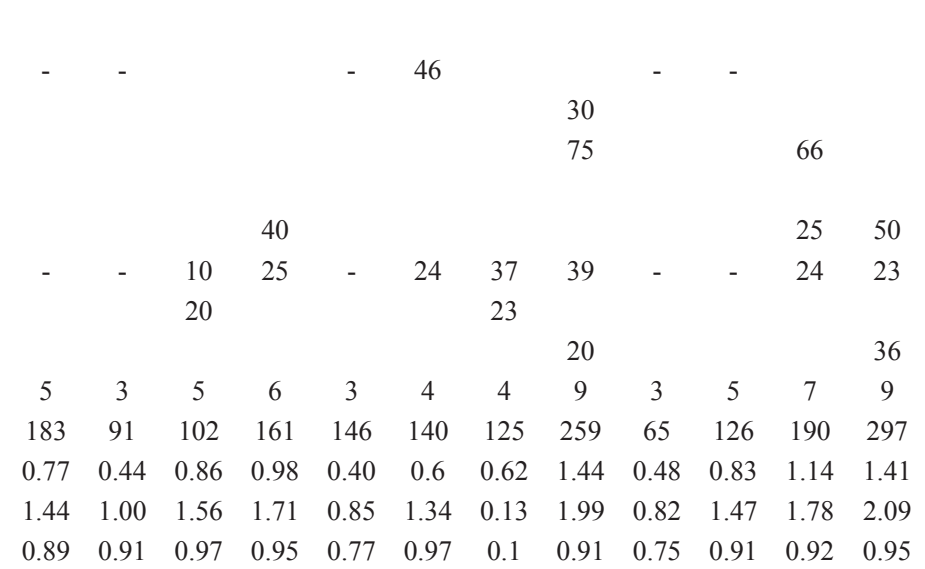


TABLE 2 (Continued)

Phytoplankton composition and abundance (cells $/ \mathrm{mL}$ ) at Tomaro and Ajegunle creeks

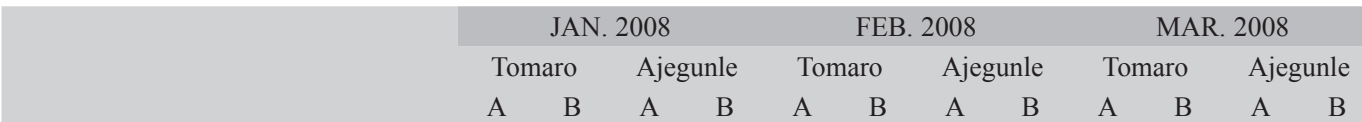

Division: Bacillariophyta

Class: Bacillariophyceae

Order1: Centrales

Aulacoseira granulata Ehr.

Coscinodiscus centralis Ehr.

C. lineatus Ehr.

$\begin{array}{ccc}- & - & 25 \\ 16 & 19 & 13\end{array}$

C. nitidus Ehr.

Cocconeis placentula Ehr.

Cyclotella meneghiana (Kutz) Grunow

Diatoma elongatum

Fragillaria construens Ehr.

Nitzschia palae (Kutzing) Wm Smith

Parabelus delogni

Pinnularia brauni

Pleurosigma strigosum W. sm.

Synedra ulna (Nitzsch) Ehr.

Division: Chlorophyta

Class: Chlorophyceae

Order: Desmidiales

Closterium lineatum Ehr.

Order: Zygnematales

Spirogyra africanum Fritch

Division: Cyanophyta

Class: Cyanophyceae

Order I: Chrooccocales

Chroococcus sp.

Order II: Hormogonales

Anabaena torulosa Lagerheim

Lyngbya martensiana

Microcystis aeruginosa Klebahn

Oscillatoria bornetti

O. formosa Bory

O. limosa Agardh

O. sancta (Kutz). Gom

Spirulina platensis Geitler

Number of species

Total number of individuals

Margalef Species Diversity (d)

Shannon-Weaver $\left(\mathrm{H}^{1}\right)$

Species Evenness (j)

$50 \quad 84$

$\begin{array}{ll}40 & 25 \\ & 20 \\ 35 & 33 \\ - & 20 \\ - & \end{array}$

24

$10 \quad 23$

45

38

$68 \quad 14$

12

26

18

25

$65 \quad 35$

70

55

20

30

10

40

30

25

5

24

13
$25 \quad 18$

$23 \quad-\quad 16$

$35 \quad 48$

28

$17 \quad 20 \quad 45$

$25 \quad-\quad-\quad 45$

$43 \quad 32$

12

$\begin{array}{cccccccccccc}4 & 7 & 9 & 14 & 2 & 5 & 4 & 8 & 4 & 4 & 9 & 9 \\ 144 & 178 & 295 & 396 & 141 & 95 & 131 & 217 & 98 & 91 & 241 & 341 \\ 0.60 & 1.16 & 1.41 & 2.17 & 0.20 & 0.88 & 0.62 & 1.30 & 0.65 & 0.67 & 1.46 & 1.37 \\ 1.15 & 1.61 & 2.03 & 2.53 & 0.63 & 1.58 & 1.20 & 2.02 & 1.32 & 1.35 & 1.96 & 2.07 \\ 0.83 & 0.83 & 0.93 & 0.96 & 0.90 & 0.98 & 0.90 & 0.97 & 0.95 & 0.97 & 0.89 & 0.94\end{array}$


Tomaro creek: The creek was alkaline (pH: 7.11 to 7.67$)$ throughout the study, probably a reflection of the buffering effect of tidal seawater experienced in the area. The creek also recorded reduced transparency values for the rainy season, possibly an outcome of mixing of the creek by more turbid floodwater inputs and re-suspension of bottom materials. The ecological factors influencing the abundance and composition of phytoplankton in coastal waters of southwestern Nigeria have been reported to be linked with the rainfall pattern (Nwankwo \& Akinsoji 1988, 1989, 1992, Olaniyan 1957,1969). The results obtained suggested that, a decrease in nutrients due to high rainfall accounted for the subsequent reduction in dissolved oxygen levels, which could result in a reduction in phytoplankton taxa. The nutrients values were higher in the dry months and coincidentally, the highest phytoplankton species diversity hence an increase in nutrient levels probably affects phytoplankton composition. There was an increase in conductivity as salinity increased, which is consistent with Brown (1972) while Medina-Júnior \& Rietzler (2005) stated that $\mathrm{BOD}_{5}$ values higher than $8.0 \mathrm{mg} / \mathrm{L}$ is an indication of high levels of pollution. The high $\mathrm{BOD}_{5}$ values recorded throughout the sampling period $(22 \mathrm{mg} / \mathrm{L}$ to $80 \mathrm{mg} / \mathrm{L})$ showed that the station was polluted, which could be linked to its closeness to the Lagos habour which has high boat traffic and also being a channel for run-offs from the city.

Tomaro and Ajegunle creeks: It is worthy to consider that only three divisions were observed for the two creeks throughout the investigation and this might be as a result of the pollution status of the creeks. Species composition of the Lagos lagoon according to Nwankwo et al. (2003) was dominantly diatoms and their dominance can be attributed to their wholly planktonic and neritic nature. Although the diatoms were more abundant the bottom dwelling forms (pennates) made up seven species while the truly planktonic forms (centric) made up six species, this may be as a result of continuous dredging in the area, previously reported by Ohimain (2004). The most abundant pennate diatoms encountered were: Nitzschia palae and Synedra ulna, according with the observations made by Adesalu et al. (2008) at Ogbe creek; Adesalu \& Nwankwo (2005) in Olero creek and Nwankwo $(1986,1991)$ in the Lagoons of South Western Nigeria. The presence and dominance of diatoms in the sampling areas conform with observations made by Adesalu \& Nwankwo $(2005,2008)$ in Olero and Abule Eledu creek respectively, Adesalu et al. (2008) in Ogbe creek, Chindah \& Pudo (1991) in Bonny River, Erondu \& Chindah (1991) in the new Calabar River, Niger Delta, Nwadiaro (1990) in the Chanomi creek system of the Niger Delta and Nwankwo $(1986,1991)$ in the Lagoons of South -western Nigeria. The blue-green algae were also observed to be higher in this study where Oscillatoria sp. is the most abundant. Nwankwo (2004) stated that the blue-green algal forms found in the creek were mostly filamentous forms and could also be opportunistic forms which by biomodification of physical processes usually proliferate to advantages of other species. The presence of Oscillatoria sp. may suggest eutrophic highly organic water. Phytoplankton recorded at both creeks include species of fresh, brackish and marine water such as, Aulacoseira granulata, Oscillatoria limosa, O. formosa, O. borneti, Lyngbya martensiana, Synedra ulna, Fragillaria construens, Coscinodiscus centralis, Pinnularia brauni, Nitzchia palae, Spirulina platensis and Closterium lineatum. This further highlights rainfall and associated floodwater conditions as key determinants of hydrology hence the phytoplankton spectrum of SouthWestern Nigeria (Olaniyan 1957, 1969, 1975). Semi-diurnal tidal oscillation resulting in dilution of the creeks polluted waters (at high tide) and eventual out flowing (at low tide) to the sea (Atlantic Ocean) may be the key factor preventing an epidemiological outbreak in the region.

\section{RESUMEN}

Como en otros países, los efectos de actividades antropogénicas en las zonas costeras y las aguas de Nigeria 
están aumentando, y las estrategias de gestión son urgentes. Durante seis meses (octubre 2007-marzo 2008) se estudió la composición del fitoplancton en relación con las características físico-químicas de dos canales en Lagos, Nigeria. Las variaciones en algunos de los parámetros físicos y químicos tales como precipitación, temperatura, salinidad, nitrato-nitrógeno, fosfato-fósforo, sulfato, salinidad, demanda biológica de oxígeno y demanda química de oxígeno; afectan la abundancia del fitoplancton. En los dos arroyos se registraron tres divisiones principales: Bacillariophyta, Chlorophyta y Cyanophyta, las diatomeas fueron el grupo más abundante observado. Características de calidad del agua reflejan el efecto de la influencia de las mareas y la consiguiente entrada de agua salada, la incursión de agua dulce y el estado de contaminación de uno de los canales, como consecuencia de actividades industriales y comerciales en la zona.

Palabras clave: estero, fitoplancton, trópicos, contaminación.

\section{REFERENCES}

Adesalu, T. A. 2007. Phytoplankton dynamics in relation to water quality indices in Lekkki lagoon, Lagos. Ph.D. Thesis, University of Lagos, Lagos, Nigeria.

Adesalu, T. A. \& D. I. Nwankwo. 2005. Studies on the phytoplankton of Olero creek and parts of Benin River, Nigeria. Ekolologia 3: 21-30.

Adesalu, T. A. \& D. I. Nwankwo. 2008. Effect of water quality indices on phytoplankton of a sluggish tidal creek in Lagos, Nigeria. Pakistan J. Biol. Sci. 11: 836-844.

Adesalu, T. A., T. O. Abiola \& O.T. Bofia. 2008. Studies on the epiphytic algae associated with two floating aquatic macrophytes in a sluggish non-tidal polluted creek in Lagos, Nigeria. Asian J. Sci. Res. 1: 363-373.

Ajibola, V.O., I.I. Funtua \& A.E. Unuaworho. 2005. Pollution studies of some water bodies in Lagos, Nigeria. Caspian J. Environ. Sci. 3: 49-54.

Akpata, T.V.I., J.A. Oyenekan \& D.I. Nwankwo. 1993. Impact of organic pollution on the Bacterial, Plankton and Benthic Population of Lagos Lagoon, Nigeria. Int. J. Ecol. Environ. Sci. 19: 73-82.

APHA. 1998. Standard methods for the evaluation of water and waste water. Washington D.C.,USA.

Blum, J.L. 1957. An ecological study on Algae of the saline siver, Michigan. Hydrobiol. 9: 361- 408.
Brown, G.I. 1972. Introduction to physical chemistry. Longman, United Kingdom.

Chapman, D. 1992. Water quality assessment. A guide to the use of biota, sediments and water in environmental monitoring. Chapman on Behalf of UNESCO, WHO and UNEP. Chapman \& Hall, London, England.

Chindah, A.C. \& J. Pudo.1991. A preliminary checklist of algae found in plankton of bonny River in Niger Delta, Nigeria. Fragm. Flor. Geobat. 36: 112-125.

Chukwu, L.O. \& D.I. Nwankwo. 2004. The impact of land based pollution on the hydrochemistry and macrocommunity of a tropical West Africa creek. Ekologia 2: 1-9.

Emmanuel, B.E. \& I.C. Onyema. 2007. The Plankton and fishes of a tropical creek in South-western Nigeria. Turk. J. Fish. Aquat. Sci. 7: 105-113.

Erondu, E.S. \& A.C. Chindah. 1991. Physico-chemical and phytoplankton changes in a tidal freshwater station of the New Calabar River South Eastern Nigeria. Environ. Ecol. 9: 561-570.

Greenaway, A.M. \& D. Gordon-Smith. 2006. The effects of rainfall on the distribution of inorganic nitrogen and phosphorus in Discovery Bay, Jamaica. Limnol. Oceanogr. 51: 2206-2220.

Hill, M.B. \& J.E. Webb. 1958. The Ecology of Lagos Lagoon. II. The Topography and Physical Features of Lagos Harbour and Lagos Lagoon. Phil. Trans. R. Soc. Lond. 241: 319-333.

Howarth, R.W. \& R. Marino. 2006. Nitrogen as the limiting nutrient for eutrophication in coastal marine ecosystems: Evolving views over three decades. Limnol. Oceanogr. 51: 364-376.

Medina-Júnior, P.B. \& A.C. Rietzler. 2005. Limnological study of a pantanal saline lake. Braz. J. Biol. 65: 756-783.

Munawar, M. 1972. Ecological studies of euglenincae in certain polluted and unpolluted environments. Hydrobiol. 39: 307-320.

Nwadiaro, C.S. 1990. A hydrobiological survey of the survey the Chanomi Creek System, lower Niger Delta, Nigeria. Limnol. 21: 263-274

Nwankwo, D.I. 1984. Seasonal changes of phytoplankton of Lagos lagoon and the adjacent sea in relation to environmental factors. Ph.D. Thesis, University of Lagos, Lagos, Nigeria. 
Nwankwo D.I. 1986. Phytoplankton of a sewage disposal site in Lagos Lagoon, Nigeria. Nig. J. Biol. Sci. 1: 89-91.

Nwankwo, D.I. 1991. A survey of the dinoflagellates of Nigeria I. Armoured dinoflagellates of Lagos Lagoon and associated tidal creeks. Nig. J. Bot. 4: 49-60.

Nwankwo, D.I. 2004. Studies on the Environmental preference of blue-green algae (cyanophyta) in Nigeria coastal waters. Nig. Environ. Soc. J. 2: 44-51.

Nwankwo, D.I. \& A. Akinsoji. 1988. Periphyton algae of a eutrophic creek and their possible use as indicator. Nig. J. Bot. 1: 47-54.

Nwankwo, D.I. \& A. Akinsoji. 1989. The benthic algal community of a sawdust deposition site in Lagos Lagoon. Int. J. Ecol. Environ. Sci. 15: 197-204.

Nwankwo, D.I. \& A. Akinsoji. 1992. Epiphyte community on water hyacinth Eichhornia crassipes (MART.) SOLMS in coastal waters of southwestern Nigeria. Arch. Hydrobiol. 124: 501-511.

Nwankwo, D.I., I.C. Onyema \& T.A. Adesalu. 2003. A survey of harmful algae in coastal waters of SouthWestern Nigeria. J. Nig. Environ. Soc. 1: 241-246.

Ohimain, E.I. 2004. Environmental impacts of dredging in the Niger Delta. Terra et Aqua 97: 9-19.

Okusipe, O.M. 2004. Lagos Lagoon coastal profile: Information database for planning theory. Lagos State Environment Report.
Olaniyan, C.I.O. 1957. The seasonal variation in plankton populations in the Lagos harbour. Nigeria. Ph.D. Thesis, University of London, London, England.

Olaniyan, C.I.O. 1969. The Seasonal variation in the hydrology and total plankton of the lagoon of SouthWestern Nigeria. Nig. J. Sci. 3: 101-119.

Olaniyan, C.I.O. 1975. The seasonal variation in the hydrological and total plankton of the lagoons of Southwestern Nigeria. Nig. J. Mar. Res. 8: 36-59.

Oyenekan, J.A. 1988. Benthic macrofauna communites of Lagos lagoon, Nigeria. Nig. J. Sci. 21: 45-51.

Palmer, C.M. 1969. A composite rating of algae tolerating pollution. J. Phycol. 5: 8-82.

Patrick, R. 1948. The structure of diatoms communities in similar ecological conditions. Am. Nat. 102: 173183.

Pielou, E.C. 1975. The measurement of diversity to different types of biological collections. J. Theor. Biol. 13: $131-144$.

Shannon, C.E. \& W.Weaver. 1963. The mathematical theory of communication. University of Illinois, Press, Urbana, 111-125pp.

Whitford, L.A. \& G.J. Schumacher. 1973. A manual of fresh water algae. Sparks, North Carolina, USA.

Wimpenny, R.S. 1966. The Plankton of the Sea. Faber and Faber Limited, London, England. 